\title{
Honoring a Legend: The William D. Nix Award
}

\section{Kaitlin Calva}

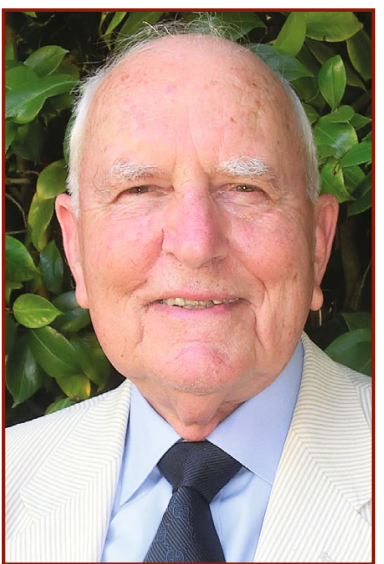

William D. Nix
Beginning in 2020, TMS is pleased to honor long-time member and TMS Fellow William D. Nix with a namesake award to celebrate his contributions to and influence on the field. The new William D. Nix Award will highlight and promote continued progress and innovation relevant to research in the underlying mechanisms and mechanical behavior of macro-, micro-, and nanoscale materials.

Through a fund established within the TMS Foundation by Nix's doctoral students the award will include a medal, certificate, and $\$ 5,000$ cash prize. The recipient will also present a lecture at the same annual meeting at which they receive their award. The inaugural William D. Nix Award will be presented at the TMS-AIME Awards Ceremony during the TMS 2020 Annual Meeting \& Exhibition, February 23-27, 2020, in San Diego, California. The deadline for nominations for this and other TMS Society and Division awards is April 1, 2019. Visit the TMS Honors and Awards website at awards.tms

\section{Fast Facts About the} William D. Nix Award

Criteria: Award recipients must have an established record of research, publications, and/or patents in the field of mechanical behavior of materials. In addition, this work must have had, or be likely to have, a significant and lasting impact on the understanding of the underlying mechanisms and/or attendant mechanical behavior of macro-, micro-, and nanoscale materials.

Award: Medal, certificate, award lecture, and a $\$ 5,000$ cash prize.

Deadline: April 1, 2019, is the deadline for nominations for the inaugural William D. Nix Award. Visit awards.tms.org for details and the nomination form.

For questions or additional information, contact Deborah Hixon, TMS Awards Program Administrator, at hixon@tms.org. .org for award criteria and nomination information.

"Bill Nix's impact on the materials community has been extraordinary," said Kevin Hemker, 2018 TMS President. He then explained why he and several of Nix's other past graduate students, wanted to create this award: "We hope to honor Bill and the tremendous legacy that he has developed and shared with the materials community; to highlight and promote continued progress and innovation relevant to research into the underlying mechanisms and mechanical behavior of materials; and to emphasize the critically impactful role that mentors play in our profession."

"Professor Nix has been a leading authority in the field of materials research for more than half a century," continued George M. Pharr, professor, Texas A\&M University, noting just one of the many reasons for the establishment of this award. "It is most fitting that he be recognized for his long history of exemplary contributions with a major TMS award bearing his name."

"By establishing this award in his honor, we will be able to ensure that his name remains prominent in front of current and future participants in the global materials science and engineering communities," elaborated David Matlock, professor, Colorado School of Mines. "His recognition of the importance of understanding mechanical properties of materials at all length scales will be maintained by the lectures to be offered by award recipients in the future. Hopefully, future recipients will also take the time to learn a little about Nix's legacy as they prepare for their lectures and share their thoughts during their presentations."

Nix's journey with TMS began 60 years ago as a graduate student at Stanford University. Upon receiving his Ph.D. in materials science in 1963, he joined Stanford faculty and became a professor in 1972. "TMS became the primary professional home for my students and me and for the fundamental work that we did together. For decades we presented our work at TMS meetings before publishing in archival journals," said Nix.

In his early career, Nix focused on studying and explaining the mechanical behavior of structural materials at high temperatures as well as creep and creep fracture. This work led to the development of new high-temperature alloys and composites for use in extreme 


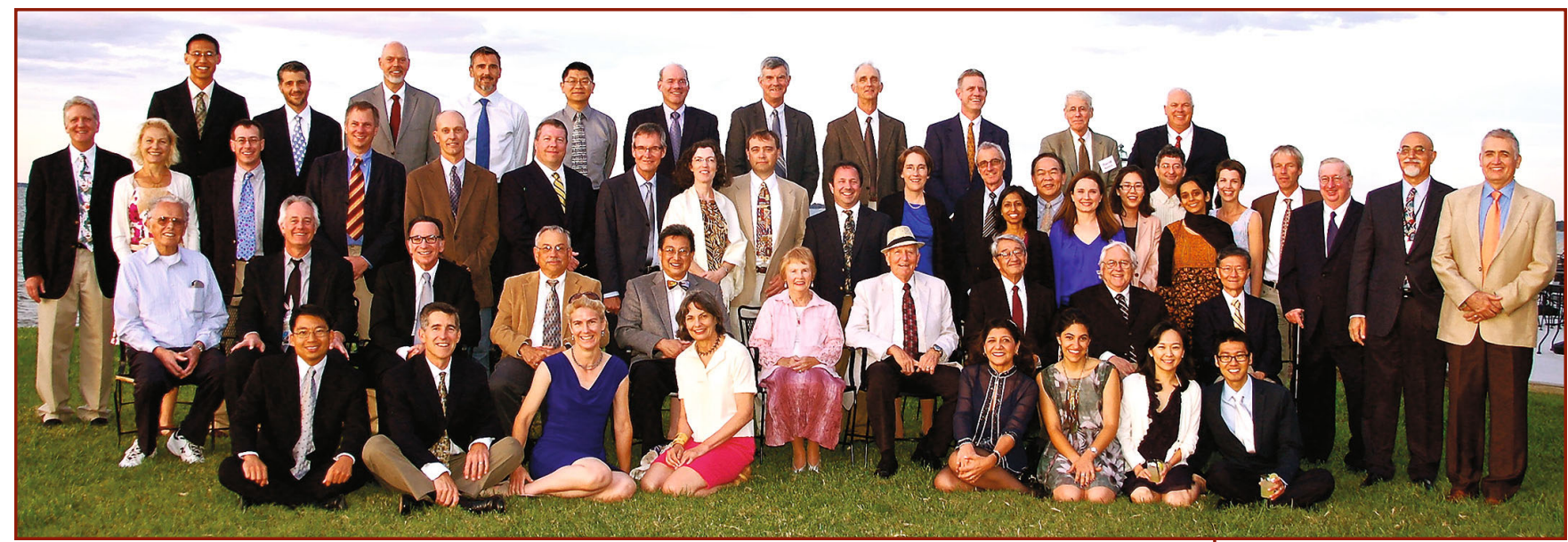

environments, work which eventually earned him election to the National Academy of Engineering (NAE) in 1987 and to the 1988 Class of TMS Fellows. In 1989 he was appointed the Lee Otterson Professor of Engineering, a position he holds today as a professor (emeritus). He also served as chair of Stanford's Department of Materials Science and Engineering from 1991 to 1996 before becoming professor emeritus in 2003.

Nix also proved to be a visionary leader in materials science and engineering through his studies in mechanical behavior of thin films used in electronic, magnetic, and optical devices. His work in this area helped to establish the field of thin film mechanical properties, providing support for the microelectronics industry. "His unique ability to evolve his interests to adapt to the changing needs of society is an attribute that truly is the mark of an excellent educator and researcher," Matlock remarked. "He has continually updated his teaching and research activities to ensure that, on graduation, his students were at the forefront of their chosen fields."

His research has earned many accolades throughout his career, most notably the 1979 Champion H. Mathewson Award, 1988 IOM/ Mehl Award, and 1995 Educator Award from TMS; the Acta Materialia Gold Medal Award in 1993; Sigma Xi's 2017 Monie A. Ferst Award; election to the American Academy of Arts and Sciences in 2002; and election to the National Academy of Sciences (NAS) in 2003 , making him one of a select number of people to be named to both the NAS and the NAE. Nix has also published more than 500 papers throughout his career, and is widely known for co-authoring two influential textbooks in the field-The Principles of Engineering Materials (1973) and Imperfections in Crystalline Solids (2016). Above all other professional and technical accomplishments, Nix knew that one of the best ways he could serve the minerals, metals, and materials community was through the education and mentorship of his students. When asked by JOM what accomplishments he was most proud of, Nix responded: "That one is easy. The achievements of the doctoral students with whom I have had the privilege to work. I recently gave a talk on the work my students have done and came to realize that almost without exception they are known for the work they did after leaving me. So their accomplishments are the ones for which I am most proud."

His students, in turn, feel honored to have known Nix. "As I look back on my career, I can truly say that I have been privileged to have had him as a mentor during my graduate education and as a friend and professional colleague since," Matlock said. "Much of my success as an educator stems from his influence on me, something for which I am truly thankful."

"It is my hope that this award and lecture would, in time, have the same impact as the Institute of Metals/Robert Franklin Mehl (IOM/Mehl) and William Hume-Rothery Awards have had," Nix said, reflecting on this latest aspect of his legacy. "Those awards have been uncannily good in identifying and recognizing the very best people in materials science and engineering. And as with those awards and lectures, my hope is that this award would focus on fundamental materials science and engineering and the people committed to such work."
Bill Nix and Jean, his wife and partner of 60 years (pictured seated,

fourth and fifth from right), and many of his past students gather for a "Nix Academic Family Reunion" on the eastern shore of Maryland several years ago.

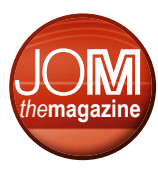

